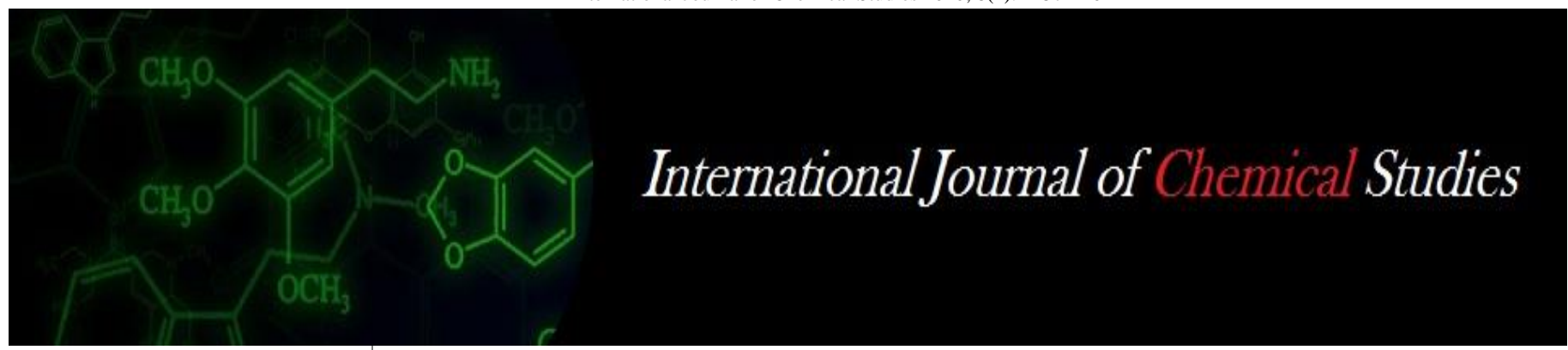

P-ISSN: 2349-8528

E-ISSN: 2321-4902

www.chemijournal.com

IJCS 2020; 8(4): 2157-2162

(C) 2020 IJCS

Received: 04-05-2020

Accepted: 06-06-2020

Solanki Bal

Department of Vegetable

Science, Bidhan Chandra Krishi

Viswavidyalaya, Mohanpur,

Nadia, West Bengal, India

Tapan Kumar Maity

Department of Vegetable

Science, Bidhan Chandra Krishi

Viswavidyalaya, Mohanpur,

Nadia, West Bengal, India

Anirban Maji

Department of Genetics and

Plant Breeding, Bidhan Chandra

Krishi Viswavidyalaya,

Mohanpur, Nadia, West Bengal,

India
Corresponding Author:

Solanki Bal

Department of Vegetable

Science, Bidhan Chandra Krishi

Viswavidyalaya, Mohanpur,

Nadia, West Bengal, India

\section{Evaluation of onion genotypes for growth, yield and quality traits under gangetic-alluvial plains of West Bengal}

\author{
Solanki Bal, Tapan Kumar Maity and Anirban Maji
}

DOI: https://doi.org/10.22271/chemi.2020.v8.i4x.9948

\begin{abstract}
Twenty-three genotypes were collected from seven different states of India and were evaluated for different vegetative, yield contributing and quality traits at ' $\mathrm{C}$ ' Block Farm, Bidhan Chandra Krishi Viswavidyalaya, Kalyani, during the rabi season of 2017-18 and 2018-19. Among all the genotypes studied, Sukhsagar was best concerning plant height at 30 DAT $(34.93 \mathrm{~cm})$ and 90 DAT $(79 \mathrm{~cm})$, number of leaves at 30 DAT $(4.47 \mathrm{~cm}), 60$ DAT $(6.07 \mathrm{~cm})$ as well as at 90 DAT $(8.67 \mathrm{~cm})$, equatorial diameter $(56.95 \mathrm{~cm})$, total soluble solids $\left(14.29^{0}\right.$ Brix $)$, dry matter $(34.56 \%)$, total sugar $(3.48 \%)$, vitamin C $(0.71$ $\mathrm{mg} / \mathrm{g})$, pyruvic acid $(3.16 \mu \mathrm{mole} / \mathrm{g})$. The genotype Arka Kirtiman was found to be superior in terms of total $(7.15 \mathrm{~kg}$ per plot) and marketable yield $(6.83 \mathrm{~kg}$ per plot). Punjab Naroya recorded the highest phenol content $(9.53 \mathrm{mg} / \mathrm{g})$. The genotypes viz., Bhima Raj, HO-3, Arka Bheem, Arka Niketan exhibited superiority in terms of number of bulbs per plot (109), number of days to maturity (137.33), polar diameter (57.33) and number of scales per bulb (10.44) respectively. Hence, for future onion improvement, these well performing genotypes can be subjected to selection or can also be used as parents in hybridization programme to obtain varieties/hybrids with desirable quality and higher yield.
\end{abstract}

Keywords: Evaluation, onion, genotypes, growth, yield and quality

\section{Introduction}

The principal Allium i.e., Onion ranks second after tomatoes in terms of value on the list of cultivated vegetable crops globally (Das et al., 2017) ${ }^{[6]}$. Onion is monocotyledonous and belongs to class Liliopsida (Fritisch and Friesen, 2002) ${ }^{[7]}$ and family Alliaceae. Since its evolution, it has become an indispensable item in the kitchen. It is also called as "queen of kitchen" as it is rich in minerals ( $\mathrm{Ca}, \mathrm{P}$, and $\mathrm{Fe})$, proteins, carbohydrates, vitamins (B and $\mathrm{C}$ ) and dietary fibres (Bal et al., 2019) ${ }^{[2,3]}$. Alachrymatic agent, quercetin, present in onion, is believed to have anti-inflammatory, anti-cholesterol, anticancer and antioxidant properties (Bal et al., 2019; Baghizadeh et al., 2009) [2,3,1]. Besides, it is rich in flavonols which have therapeutic properties (Javadzadeh et al., 2009) ${ }^{[9]}$. Onion accounts for about 22.18 per cent of the area under cultivation and 18.78 per cent of the production of vegetable crops in the world (Ram and Kumar 2018) ${ }^{[10]}$. In India, Maharashtra is one of the leading growing states, while the other important growing states are Karnataka, Andhra Pradesh, Madhya Pradesh, Gujarat, Haryana, Rajasthan, Bihar, Uttar Pradesh and Tamil Nadu. About $70 \%$ of total foreign exchange comes from fresh export of onion (Jain 2012) ${ }^{[8]}$. The high remunerative returns gave wider acceptance of this crop among the farmers. Despite this, the average productivity of onion in India is low i.e., 16.00 tonnes per hectare (Ram and Kumar 2018) ${ }^{[10]}$ against 22 tonnes/ha in China, 28.9 tonnes/ha in Turkey and 33.7 tonnes/ha in Egypt (Das et al., 2017) ${ }^{[6]}$. On the other hand, for local and processing markets, quality of the bulb is also a very important factor. Considering the importance of this crop, there is an urgent need for the development of varieties suitable for different agro-ecological conditions. Therefore, to have impressive genotype collection it is necessary to breed genotypes for higher yield and quality (Bal et al., 2020) ${ }^{[4]}$. Thus, to identify the superior genotype(s) suitable for cultivation in the Gangetic plans of West Bengal, the present experiment was carried out to evaluate germplasms from the existing gene pool. 


\section{Materials and Methods}

The experiment was conducted at ' $\mathrm{C}$ ' Block Farm of Bidhan Chandra Krishi Viswavidyalaya, Kalyani, Nadia, West Bengal with twenty open-pollinated varieties, two-hybrid varieties and one local variety as a standard check (cv. Sukhsagar) during the rabi season of 2017-2018 and 20182019 following Randomized Block Design with three replications with an optimum plot size of $2 \mathrm{~m} \times 1.5 \mathrm{~m}$ and spacing of $15 \mathrm{~cm}$ row to row and $10 \mathrm{~cm}$ plant to plant. Observation on growth parameters i.e. plant height and the number of leaves were recorded from ten randomly selected plants in each replication at 30, 60 and 90 days after transplanting (DAT). Bulb and quality parameters, viz., number of bulbs per plot, number of days taken to maturity, polar diameter, equatorial diameter, neck thickness, number of scales per bulb, bolting (\%), TSS of the bulb ( ${ }^{\circ}$ Brix), dry matter $(\%)$, total sugar $(\%)$, vitamin $\mathrm{C}(\mathrm{mg} / \mathrm{g})$, pyruvic acid $(\mu \mathrm{mole} / \mathrm{g})$, total phenol $(\mathrm{mg} / \mathrm{g})$ were recorded from ten randomly selected bulbs after harvest. The yield parameters viz., the average weight of ten bulbs ( $\mathrm{kg}$ ), total yield ( $\mathrm{kg}$ per plot), marketable yield ( $\mathrm{kg}$ per plot), unmarketable yield ( $\mathrm{kg}$ per plot) were calculated after the bulbs were harvested from the respective plots The severity of purple blotch disease was recorded 90 days after transplanting. The development of the symptoms and the severity of the disease was recorded by observing all the plants in each genotypes separately, using 05 scale as given by Bhangale and Joi (1985) ${ }^{[5]}$. The statistical analysis was carried out using OPSTAT software packages.

Table 1: List of genotypes and along with their sources

\begin{tabular}{|c|c|c|}
\hline Sl. No. & Name of the genotype & Sources \\
\hline 1 & Arka Bheem & ICAR-IIHR, Bangalore \\
\hline 2 & Arka Kirtiman & ICAR-IIHR, Bangalore \\
\hline 3 & Arka Lalima & ICAR-IIHR, Bangalore \\
\hline 4 & Arka Niketan & ICAR-IIHR, Bangalore \\
\hline 5 & Akola Safed & PDKV, Akola, Maharastra \\
\hline 6 & Agrifound Light Red & NHRDF, Nasik, Maharastra \\
\hline 7 & Bhima Dark Red & DOGR, Rajgurunagar \\
\hline 8 & Bhima Kiran & DOGR, Rajgurunagar \\
\hline 9 & Bhima Raj & DOGR, Rajgurunagar \\
\hline 10 & Bhima Red & DOGR, Rajgurunagar \\
\hline 11 & Bhima Safed & DOGR, Rajgurunagar \\
\hline 12 & Bhima Shakti & DOGR, Rajgurunagar \\
\hline 13 & Bhima Subhra & DOGR, Rajgurunagar \\
\hline 14 & Bhima Super & DOGR, Rajgurunagar \\
\hline 15 & Bhima Sweta & DOGR, Rajgurunagar \\
\hline 16 & Hisar-2 & HAU, Hisar \\
\hline 17 & Hisar-4 & HAU, Hisar \\
\hline 18 & Kalyanpur Red Round & CSAUAT, Kanpur \\
\hline 19 & L-28 & NHRDF, Nasik, Maharastra \\
\hline 20 & Onion HO-3 & HAU, Hisar \\
\hline 21 & PRO-6 & PAU,Ludhiana, Punjab \\
\hline 22 & Punjab Naroya & PAU,Ludhiana, Punjab \\
\hline 23 & Sukhsagar & Local market \\
\hline
\end{tabular}

\section{Results and Discussion}

There were significant differences among the genotypes for all the traits under study. The mean/average performances for evaluation of genotypes and detailed explanation of different characters were recorded during experimentation given below:

\section{a. Plant height at 30 DAT $(\mathrm{cm})$}

The plant height at 30 DAT ranged from $21.72 \mathrm{~cm}$ to 34.93 $\mathrm{cm}$. The general mean of the character was $27.56 \mathrm{~cm}$. Maximum plant height was recorded in Sukhsagar $(34.93 \mathrm{~cm}$ ) which was statistically on par with that of Arka Kirtiman $(34.46 \mathrm{~cm})$, Hisar-4 $(33.84 \mathrm{~cm})$, Bhima Red $(33.44 \mathrm{~cm})$, Punjab Naroya $(31.88 \mathrm{~cm})$, L-28 $(32.06 \mathrm{~cm})$ and Akola Safed $(31.59 \mathrm{~cm})$. The minimum plant height for this character was observed in Arka Niketan $(21.72 \mathrm{~cm})$.

\section{b. Plant Height (cm) at 60 DAT}

The plant height at 60 DAT was ranged from $37.84 \mathrm{~cm}$ to $64.52 \mathrm{~cm}$. The general mean of the character was $53.49 \mathrm{~cm}$. The maximum plant height at 60 DAT was recorded in Bhima Dark red $(64.52 \mathrm{~cm})$ which was statistically at par with Hisar$4(61.68 \mathrm{~cm})$ and the minimum plant height at 60 DAT was recorded in Kalyanpur Red Round $(37.84 \mathrm{~cm})$.

\section{c. Plant Height (cm) at 90 DAT}

The plant height at 90 DAT ranged from $53.9 \mathrm{~cm}$ to $79 \mathrm{~cm}$. The general mean of the character was $64.35 \mathrm{~cm}$. The maximum plant height was recorded in Sukhsagar $(79 \mathrm{~cm})$, which was taken as a standard check and was statistically on par with Bhima Dark Red $(72.68 \mathrm{~cm})$, Arka Lalima $(70.86 \mathrm{~cm})$, Hisar-4 $(69.84 \mathrm{~cm})$. The minimum plant height at 60 DAT was recorded in Bhima Red $(53.9 \mathrm{~cm})$.

\section{d. Number of Leaves at 30 DAT}

The range for this character varied from 3.26 to 4.46 with a general mean of 3.87. The maximum number of leaves was recorded in Sukhsagar (4.46) which was statistically at par with Punjab Naroya (4.53), Arka Kirtiman (4.53), L-28 (4.4), Bhima Kiran (4.4), H0-3 (4.26), Arka Niketan (4.26), Kalyanpur Red Round (4.2), Bhima Raj (4.2), Bhima Super (4.13), Akola Safed (4.13), Agrifound Light Red (4.13), Bhima Red (4.13) and Bhima Shakti (4.13).The minimum number of leaves was recorded in PRO-6 (3.26) and Arka Bheem (3.26).

\section{e. Number of leaves at 60 DAT}

Significant variations were found among all the genotypes for this trait. The range for this trait varied from 4.6 to 6.06 with the general mean of 5.25. The maximum number of leaves at 60 DAT was recorded in Sukhsagar (6.06) and the minimum value was recorded in Hisar-4 (4.6).

\section{f. Number of leaves at 90 DAT}

There were significant variations among all the genotypes for this character. The range for this trait varied from 6.2 to 8.66 with the general mean of 6.94 . The highest number of leaves at 90 DAT was observed in Sukhsagar (8.66), which was statistically on par with Bhima Kiran (8.43) and Arka Niketan (8.03), whereas, the lowest number of leaves at 90 DAT was observed in Onion HO-3 (6.2).

\section{g. Days to maturity}

There were significant variations for this trait among all the genotypes. The range of this trait varied from 116 to 137.33 with the general mean of 129.04. The maximum number of days to attain maturity was required by genotype HO-3 (137.33), which was statistically at par with Hisar-2 (136.66), Bhima Safed (136.33), Bhima Red (135.33), Bhima Sweta (134.33) and Sukhsagar (134), whereas the minimum number of days to attain maturity were observed in Arka Niketan (116) and Akola Safed (116).

\section{h. Polar diameter $(\mathbf{m m})$}

Significant variations were found among all the genotypes for this trait. The range for this trait was varied from 43.48 to 
$57.33 \mathrm{~mm}$ with the general mean of $53.19 \mathrm{~mm}$. The maximum polar diameter was observed in Arka Bheem (57.33 mm) which was statistically at par with Bhima Dark Red (56.98mm), Akola Safed (56.98 mm), Kalyanpur Red Round (56.85 mm), Arka Lalima (56.39 mm), Arka Kirtiman (56.02 $\mathrm{mm})$, Sukhsagar (55.17 mm), Bhima Subhra (55.08 mm), HO-3 (55.05 mm), Hisar-4 (53.99 mm), Punjab Naroya (53.95 mm), PRO-6 (53.78 mm), Bhima Shakti $(53.39 \mathrm{~mm})$ and L-28 $(53.35 \mathrm{~mm})$, whereas, the minimum polar diameter was observed in Bhima Red (43.48 mm).

\section{i. Equatorial Diameter (mm)}

Significant variations were found among all the genotypes for this character. The range for this trait varied from $43.58 \mathrm{~mm}$ to $56.95 \mathrm{~mm}$ with the general mean of $50.18 \mathrm{~mm}$. The highest equatorial diameter was observed in Sukhsagar $(56.95 \mathrm{~mm})$, which was statistically on par with Bhima Kiran $(55.73 \mathrm{~mm})$, Bhima Dark Red (55.17 mm), Bhima Subhra (54.91 mm), Arka Kirtiman (53.91 mm), Arka Niketan (52.91 mm) Hisar-2 (52.88 mm), Bhima Sweta (52.44 mm), Bhima Raj (52.34 $\mathrm{mm})$, whereas, the lowest equatorial diameter was observed in Bhima Super (43.58 mm).

\section{j. $\quad$ Neck Thickness (mm)}

Significant variations were found among all the genotypes for this trait. The range for this trait varied from $5.49 \mathrm{~mm}$ to 9.25 $\mathrm{mm}$ with the general mean of $7.44 \mathrm{~mm}$. The maximum neck thickness was recorded in Hisar-4 $(9.25 \mathrm{~mm})$, which was statistically at par with Sukhsagar $(8.73 \mathrm{~mm})$ and minimum neck thickness was recorded in Bhima Raj (5.49 mm).

\section{k. Number of scales per bulb}

There were significant variations among all the genotypes for this character. The range for this trait varied from 6.11 to 10.44 with general mean of 15.04. The maximum number of scales per bulb was recorded in Arka Niketan (10.44), which was statistically on par with Sukhsagar (10.33) and Arka Kirtiman (10.22), whereas the minimum number of scales per bulb was observed in Bhima Shakti (6.11).

\section{l. Bolting (\%)}

Significant variations were found among all the genotypes for this trait. The range for this trait varied from 0.67 to $4.66 \%$ with the general mean of $2.47 \%$. The maximum bolting percentage was observed in L-28 (4.66) which was statistically at par with Agrifound Light Red (4.44\%), Bhima Shakti (4\%) and Bhima Safed (4.22\%). The minimum bolting percentage was observed in $\mathrm{HO}-3(0.67 \%)$.

\section{m. Number of bulbs per plot}

There were significant variations for this trait among all the genotypes. The range of variation was from 64 to 109 with a general mean of 89.27 . The maximum number of bulbs per plot was observed in Bhima Raj (109), which was statistically at par with Bhima Safed (108.66), Sukhsagar (108), Arka Kirtiman (105.66), Bhima Kiran (103) whereas the minimum number of bulbs per plot were observed in Bhima Red (64).

\section{n. Vitamin $\mathbf{C}(\mathbf{m g} / \mathrm{g})$}

Significant variations for this trait were observed among all the genotypes. The range of variation was from 0.12 to 0.71 $\mathrm{mg} / \mathrm{g}$ with the general mean of $0.35 \mathrm{mg} / \mathrm{g}$. The maximum vitamin C content was observed in Sukhsagar $(0.71 \mathrm{mg} / \mathrm{g})$ which was statistically on par with Arka Kirtiman $(0.66 \mathrm{mg} / \mathrm{g})$ and Bhima Shakti $(0.59 \mathrm{mg} / \mathrm{g})$. The minimum value for this character was observed in Bhima Subhra $(0.12 \mathrm{mg} / \mathrm{g})$.

\section{o. Pyruvic acid ( $\mu$ mole/g)}

There were significant variations for this trait among all the genotypes. The range of this trait varied from 0.78-3.16 $\mu$ mole $/ g$ with the general mean value of $1.48 \mu$ mole/g. The maximum amount of Pyruvic acid was observed in Sukhsagar (3.16 $\mu \mathrm{mole} / \mathrm{g})$ followed by Arka Lalima $(2.29 \mu \mathrm{mole} / \mathrm{g})$ and Bhima Shakti $(2.25 \mu \mathrm{mole} / \mathrm{g})$, whereas, the minimum pyruvic acid content was observed in HO-3 (0.78 $\mu$ mole/g).

\section{p. Total sugar $(\%)$}

Significant variations for this trait were observed among all the genotypes. The range of variation was from 0.81 to $3.48 \%$ with the general mean value of $1.73 \%$. The maximum total sugar content was observed in Sukhsagar $(3.48 \%)$ which was statistically at par with Bhima Sweta $(2.50 \%)$ and Bhima Kiran $(2.17 \%)$. The minimum total sugar content was observed in Hisar-2 (0.81\%).

\section{q. Dry matter (\%)}

There were significant variations for this trait among all the genotypes. The range for this trait was varied from 0.21 $34.56 \%$ with the general mean value of $11.51 \%$. The maximum dry weight was observed in Sukhsagar (34.56\%) followed by Agrifound Light Red (25.73\%) and Bhima Kiran $(24.66 \%)$, whereas, minimum dry weight was observed in Kalyanpur Red Round (0.21\%).

\section{r. Total Soluble Solids $\left({ }^{0}\right.$ B $)$}

Significant variations for this trait were observed among all the genotypes. The range of variation was from $6.37^{\circ}-14.14^{\circ} \mathrm{B}$ with a general mean value of $9.46^{\circ} \mathrm{B}$. The highest total soluble solids content was observed in Sukhsagar $\left(14.14^{\circ} \mathrm{B}\right)$ which was statistically on par with Arka Kirtiman $\left(13.77^{\circ} \mathrm{B}\right)$ and Bhima Shakti $\left(12.65^{\circ} \mathrm{B}\right)$. The minimum total soluble solids content was observed in Hisar-4 $\left(6.37^{\circ} \mathrm{B}\right)$.

\section{S. Phenol (mg/g)}

There were significant variations for this trait among all the genotypes. The range of this trait varied from 2.61 to $8.2 \mathrm{mg} / \mathrm{g}$ with the general mean of $5.00 \mathrm{mg} / \mathrm{g}$. The maximum phenol content was observed in Sukhsagar $(8.2 \mathrm{mg} / \mathrm{g})$ followed by Bhima Dark Red $(7.71 \mathrm{mg} / \mathrm{g})$ and Arka Niketan $(7.41 \mathrm{mg} / \mathrm{g})$, whereas, minimum phenol content was observed in Bhima Sweta $(2.61 \mathrm{mg} / \mathrm{g})$.

\section{t. Average weight of ten bulbs}

Significant variations for this trait were observed among all the genotypes. The range of variation was from $0.42 \mathrm{~kg}$ to $0.67 \mathrm{~kg}$ with the general mean of $0.55 \mathrm{~kg}$. The maximum average weight of ten bulbs was observed in Arka Niketan $(0.69 \mathrm{~kg})$ which was statistically on par with Bhima Kiran $(0.67 \mathrm{~kg})$, Bhima Subhra $(0.66 \mathrm{~kg})$, Sukhsagar $(0.66 \mathrm{~kg})$. The minimum average weight of ten bulbs was observed in $\mathrm{HO}-3$ $(0.42 \mathrm{~kg})$.

\section{u. Total Yield (kg/plot)}

Significant differences were observed for all the genotypes for this trait. The range of variation was from 1.08 to $7.15 \mathrm{~kg}$ per plot with the general mean of $3.02 \mathrm{~kg}$ per plot. The maximum yield per plot was observed in Arka Kirtiman (7.15 kg per plot) followed by Arka Niketan $(6.18 \mathrm{~kg}$ per plot), Akola Safed (5.39 kg per plot), Punjab Naroya (5.36 kg per plot). 
The minimum yield per plot was observed in Bhima Red (1.08 kg per plot).

\section{v. Marketable yield (kg/plot)}

Among all the genotypes there were significant variations for this trait. The range of variation was from 1.03 to $5.49 \mathrm{~kg}$ with the general mean of $2.58 \mathrm{~kg}$. The highest marketable yield was observed in Arka Lalima $(5.49 \mathrm{~kg}$ ), followed by Arka Niketan $(5.28 \mathrm{~kg})$, which was higher than the standard check variety Sukhsagar $(1.78 \mathrm{~kg})$. The lowest marketable yield was observed in Bhima Red $(1.03 \mathrm{~kg})$.

\section{w. Unmarketable yield (kg/plot)}

Among all the genotypes there were significant variations for this trait. The range of variation was from 0.03 to $0.68 \mathrm{~kg}$ with the general mean of $0.18 \mathrm{~kg}$. The highest unmarketable yield was observed in Bhima Kiran $(0.68 \mathrm{~kg})$ which was statistically at par with Sukhsagar $(0.65 \mathrm{~kg}$ per plot), Kalyanpur Red Round (0.55 kg per plot), Punjab Naroya
(0.33 kg per plot). The lowest unmarketable yield was observed in $\mathrm{HO}-3(0.03 \mathrm{~kg}$ per plot).

\section{x. Severity of purple blotch disease (\%)}

Significant differences were observed for all the genotypes for the severity of purple blotch disease. The range of variation was observed from 1.23 to $28.49 \%$ with the general mean of $16.18 \%$. The maximum severity of the disease was observed in Bhima Sweta $(28.49 \%)$ which was statistically on par with Bhima Super (26.89\%), Agrifound Light Red (25.92\%) and Hisar-2 (24.68\%). Minimum disease severity was observed in Punjab Naroya (1.23\%), Arka Lalima (1.23\%) and Arka Kirtiman (1.23\%).

\section{y. Storage loss $(\%)$}

The range of this trait varied from 0.27 to $8.27 \%$ with a general mean of $1.07 \%$. The maximum storage loss was observed in Agrifound Light Red (8.27\%) whereas the minimum storage loss was observed in PRO-6 (0.27\%).

Table 2: Mean performance of growth parameters in twenty-three onion genotypes

\begin{tabular}{|c|c|c|c|c|c|c|c|}
\hline Genotypes & \begin{tabular}{|l} 
Plant height at \\
30DAT $(\mathrm{cm})$
\end{tabular} & $\begin{array}{l}\text { Plant height at } \\
60 \text { DAT }(\mathrm{cm})\end{array}$ & $\begin{array}{l}\text { Plant height at } \\
\text { 90 DAT }(\mathrm{cm})\end{array}$ & \begin{tabular}{|c|} 
No. of leaves \\
at 30 DAT \\
\end{tabular} & $\begin{array}{c}\text { No. of leaves } \\
\text { at } 60 \text { DAT }\end{array}$ & $\begin{array}{c}\text { No. of leaves } \\
\text { at } 90 \text { DAT }\end{array}$ & $\begin{array}{l}\text { No. of days } \\
\text { to maturity }\end{array}$ \\
\hline Bhima Sweta & 24.04 & 55.36 & 65.53 & 3.4 & 5.53 & 7.33 & 134.33 \\
\hline Hisar 4 & 33.84 & 61.68 & 69.84 & 3.53 & 4.6 & 6.73 & 130.33 \\
\hline Punjab Naroya & 31.88 & 58.94 & 66.19 & 4.53 & 4.53 & 6.7 & 121.66 \\
\hline Bhima Dark Red & 25.67 & 64.52 & 72.68 & 3.06 & 5.33 & 7.4 & 129.33 \\
\hline PRO-6 & 22.51 & 55.94 & 67.10 & 3.26 & 5.2 & 7.46 & 132.33 \\
\hline Bhima Super & 24.51 & 47.96 & 67.24 & 4.13 & 5.4 & 6.3 & 136.33 \\
\hline Arka Lalima & 23.11 & 44.06 & 70.86 & 3.46 & 5.13 & 6.4 & 117.33 \\
\hline Bhima Safed & 29.52 & 48.34 & 62.04 & 3.6 & 5.2 & 7.3 & 136.33 \\
\hline L-28 & 32.06 & 55.48 & 62.51 & 4.4 & 5.06 & 7.16 & 132.33 \\
\hline HO-3 & 26.47 & 57.32 & 66.05 & 4.26 & 5.53 & 6.2 & 137.33 \\
\hline Akola Safed & 31.59 & 51.26 & 62.66 & 4.13 & 5.4 & 7.9 & 116 \\
\hline Agrifound Light Red & 28.07 & 54.85 & 57.32 & 4.13 & 5.46 & 7.4 & 136 \\
\hline Bhima Subhra & 24.61 & 54.40 & 67.56 & 3.33 & 5.53 & 7.26 & 129.33 \\
\hline Arka Bheem & 25.98 & 54.91 & 59.2 & 3.26 & 4.73 & 7.06 & 126.66 \\
\hline Kalyanpur Red Round & 26.43 & 37.84 & 61.2 & 4.2 & 5.06 & 7.4 & 124.66 \\
\hline Bhima Raj & 24.86 & 52.77 & 56.84 & 4.2 & 5.33 & 7.7 & 127.66 \\
\hline Bhima Shakti & 25.21 & 52.21 & 60.46 & 4.13 & 5.4 & 7.6 & 125.33 \\
\hline Hisar 2 & 23.06 & 51.99 & 57.46 & 3.2 & 5.4 & 6.5 & 136.66 \\
\hline Arka Kirtiman & 34.46 & 52.13 & 63.1 & 4.53 & 5.2 & 7.4 & 118.66 \\
\hline Arka Niketan & 21.72 & 52.74 & 62.56 & 4.26 & 5.6 & 8.03 & 116 \\
\hline Bhima Red & 33.44 & 53.87 & 53.9 & 4.13 & 4.8 & 7.16 & 135.33 \\
\hline Bhima Kiran & 25.97 & 53.82 & 68.73 & 4.4 & 5.4 & 8.43 & 134 \\
\hline Sukhsagar & 34.93 & 57.96 & 79 & 4.46 & 6.06 & 8.66 & 134 \\
\hline $\mathrm{CD}(0.05)$ & 5.01 & 3.59 & 9.75 & 0.43 & 0.41 & 0.72 & 3.40 \\
\hline $\mathrm{SE}(\mathrm{m}) \pm$ & 1.75 & 1.25 & 3.41 & 0.15 & 0.14 & 0.25 & 1.19 \\
\hline $\mathrm{CV}$ & 11.02 & 4.07 & 9.17 & 6.72 & 4.75 & 6.03 & 1.59 \\
\hline
\end{tabular}

Table 3: Mean performance of bulb parameters in twenty-three onion genotypes

\begin{tabular}{|c|c|c|c|c|c|c|}
\hline Genotypes & $\begin{array}{c}\text { Polar diameter } \\
(\mathbf{m m})\end{array}$ & $\begin{array}{c}\text { Equatorial } \\
\text { diameter(mm) }\end{array}$ & $\begin{array}{c}\text { Neck thickness } \\
(\mathbf{m m})\end{array}$ & $\begin{array}{c}\text { Number of scales } \\
\text { per bulb }\end{array}$ & $\begin{array}{c}\text { Bolting } \\
\text { \% }\end{array}$ & $\begin{array}{c}\text { Number of bulbs } \\
\text { per plot }\end{array}$ \\
\hline Bhima Sweta & 46.07 & 52.44 & 8.16 & 7.22 & 1.66 & 85.33 \\
\hline Hisar 4 & 53.99 & 53.54 & 9.25 & 6.33 & 4 & 85.33 \\
\hline Punjab Naroya & 53.95 & 45.62 & 8.49 & 7.32 & 3.11 & 107 \\
\hline Bhima Dark Red & 56.98 & 55.17 & 8.13 & 6.32 & 4 & 92.66 \\
\hline PRO-6 & 53.78 & 49.36 & 7.17 & 7.21 & 0.99 & 96.66 \\
\hline Bhima Super & 55.82 & 43.58 & 8.09 & 7.44 & 1.10 & 75 \\
\hline Arka Lalima & 56.39 & 44.11 & 8.15 & 7.22 & 1.44 & 75.33 \\
\hline Bhima Safed & 52.20 & 44.59 & 7.30 & 6.55 & 4.22 & 108.66 \\
\hline L-28 & 53.35 & 43.40 & 6.91 & 7.44 & 4.66 & 82.33 \\
\hline HO-3 & 55.05 & 50.82 & 7.59 & 6.55 & 0.67 & 82.66 \\
\hline Akola Safed & 56.98 & 45.85 & 7.59 & 9.44 & 1.77 & 85.33 \\
\hline Agrifound Light Red & 56.17 & 47.47 & 6.69 & 6.44 & 4.44 & 97 \\
\hline Bhima Subhra & 55.08 & 54.91 & 7.54 & 6.54 & 2.77 & 98 \\
\hline Arka Bheem & 57.33 & 46.1 & 7.56 & 10.22 & 2.44 & 64.33 \\
\hline
\end{tabular}




\begin{tabular}{|c|c|c|c|c|c|c|}
\hline Kalyanpur Red Round & 56.85 & 49.05 & 8.44 & 8.44 & 1.00 & 83.33 \\
\hline Bhima Raj & 50.6 & 52.34 & 5.49 & 7.44 & 1.89 & 109 \\
\hline Bhima Shakti & 53.39 & 55.09 & 6.41 & 6.11 & 4 & 75 \\
\hline Hisar 2 & 46.19 & 52.88 & 6.44 & 6.44 & 2.44 & 76 \\
\hline Arka Kirtiman & 56.02 & 53.91 & 7.55 & 10.22 & 1.33 & 105.66 \\
\hline Arka Niketan & 46.99 & 52.91 & 6.87 & 10.44 & 2.89 & 93.66 \\
\hline Bhima Red & 43.48 & 48.30 & 6.25 & 8.33 & 1.55 & 64 \\
\hline Bhima Kiran & 51.52 & 55.73 & 6.29 & 7.22 & 3.00 & 103 \\
\hline Sukhsagar & 55.17 & 56.95 & 8.73 & 10.33 & 1.55 & 108 \\
\hline $\mathrm{CD}(0.05)$ & 4.58 & 4.82 & 0.48 & 0.51 & 1.12 & 8.38 \\
\hline $\mathrm{SE}(\mathrm{m}) \pm$ & 1.60 & 1.68 & 0.16 & 0.18 & 0.39 & 2.93 \\
\hline $\mathrm{CV}$ & 5.22 & 5.82 & 3.91 & 4.06 & 27.54 & 5.68 \\
\hline
\end{tabular}

Table 4: Mean performance of quality parameters in twenty-three onion genotypes

\begin{tabular}{|c|c|c|c|c|c|c|}
\hline Genotypes & Total soluble solids ( $\left.{ }^{0} \mathrm{Brix}\right)$ & Dry matter\% & Total sugar\% & Vitamin C (mg/g) & Pyruvic acid $(\mu \mathrm{mole} / \mathrm{g})$ & Phenol (mg/g) \\
\hline Bhima Sweta & 7.11 & 8.61 & 2.50 & 0.56 & 1.21 & 2.61 \\
\hline Hisar 4 & 6.37 & 2.52 & 2.08 & 0.16 & 1.12 & 3.06 \\
\hline Punjab Naroya & 7.43 & 6.57 & 1.29 & 0.62 & 0.95 & 9.53 \\
\hline Bhima Dark Red & 6.42 & 4.60 & 1.56 & 0.13 & 0.94 & 7.71 \\
\hline PRO-6 & 7.21 & 5.38 & 1.36 & 0.25 & 1.08 & 4.22 \\
\hline Bhima Super & 7.44 & 14.65 & 1.31 & 0.45 & 1.75 & 2.81 \\
\hline Arka Lalima & 7.56 & 13.83 & 1.82 & 0.25 & 2.29 & 4.27 \\
\hline Bhima Safed & 6.55 & 15.46 & 2.19 & 0.16 & 1.58 & 2.70 \\
\hline L-28 & 7.44 & 1.50 & 1.74 & 0.12 & 1.74 & 3.71 \\
\hline $\mathrm{HO}-3$ & 6.45 & 5.54 & 0.95 & 0.11 & 0.78 & 2.82 \\
\hline Akola Safed & 8.38 & 8.37 & 1.03 & 0.24 & 1.09 & 7.15 \\
\hline Agrifound Light Red & 11.22 & 25.73 & 2.01 & 0.22 & 1.54 & 6.3 \\
\hline Bhima Subhra & 11.42 & 11.65 & 1.51 & 0.12 & 1.12 & 3.17 \\
\hline Arka Bheem & 13.5 & 17.4 & 1.63 & 0.22 & 1.29 & 4.6 \\
\hline Kalyanpur Red Round & 12.6 & 0.21 & 1.16 & 0.32 & 1.45 & 5.08 \\
\hline Bhima Raj & 10.63 & 1.48 & 1.63 & 0.49 & 1.24 & 4.21 \\
\hline Bhima Shakti & 12.65 & 18.01 & 2.16 & 0.59 & 2.25 & 3.17 \\
\hline Hisar 2 & 7.22 & 5.65 & 0.81 & 0.48 & 1.74 & 4.9 \\
\hline Arka Kirtiman & 13.77 & 0.73 & 2.00 & 0.66 & 1.77 & 6.76 \\
\hline Arka Niketan & 14.14 & 14.55 & 2.15 & 0.50 & 1.13 & 7.41 \\
\hline Bhima Red & 9.4 & 14.82 & 1.34 & 0.30 & 1.18 & 6.07 \\
\hline Bhima Kiran & 8.41 & 24.66 & 2.17 & 0.37 & 1.74 & 4.5 \\
\hline Sukhsagar & 14.29 & 34.56 & 3.48 & 0.71 & 3.16 & 8.2 \\
\hline $\mathrm{CD}(0.05)$ & 1.52 & 2.85 & 1.03 & 0.07 & 0.81 & 0.42 \\
\hline $\mathrm{SE}(\mathrm{m}) \pm$ & 0.53 & 0.99 & 0.36 & 0.02 & 0.28 & 0.14 \\
\hline $\mathrm{CV}$ & 0.75 & 15.50 & 35.94 & 12.50 & 33.20 & 0.21 \\
\hline
\end{tabular}

Table 5: Mean performance of yield and other parameters in twenty-three onion genotypes

\begin{tabular}{|c|c|c|c|c|c|c|}
\hline Genotypes & \begin{tabular}{|c|} 
Average weight of \\
10 bulbs (kg)
\end{tabular} & $\begin{array}{c}\text { Total yield } \\
(\mathrm{kg} / \mathrm{plot})\end{array}$ & $\begin{array}{c}\text { Marketable } \\
\text { yield (kg/plot) }\end{array}$ & $\begin{array}{l}\text { Unmarketable } \\
\text { yield (kg/plot) }\end{array}$ & $\begin{array}{l}\text { Severity of purple } \\
\text { blotch disease }(\%)\end{array}$ & $\begin{array}{l}\text { Storage } \\
\text { loss }(\%)\end{array}$ \\
\hline Bhima Sweta & 0.64 & 1.66 & 1.49 & 0.05 & 28.49 & 0.72 \\
\hline Hisar 4 & 0.54 & 1.42 & 1.32 & 0.21 & 23.45 & 1.06 \\
\hline Punjab Naroya & 0.55 & 5.36 & 4.37 & 0.33 & 1.23 & 1.60 \\
\hline Bhima Dark Red & 0.62 & 2.74 & 2.68 & 0.04 & 12.34 & 2.24 \\
\hline PRO-6 & 0.52 & 2.75 & 1.38 & 0.20 & 16.04 & 1.74 \\
\hline Bhima Super & 0.45 & 1.57 & 1.53 & 0.03 & 26.89 & 1.28 \\
\hline Arka Lalima & 0.54 & 6.24 & 5.49 & 0.07 & 1.23 & 2.40 \\
\hline Bhima Safed & 0.47 & 1.42 & 1.33 & 0.07 & 22.14 & 2.23 \\
\hline L-28 & 0.53 & 2.97 & 2.72 & 0.05 & 13.57 & 2.86 \\
\hline $\mathrm{HO}-3$ & 0.42 & 1.80 & 1.77 & 0.03 & 24.55 & 1.41 \\
\hline Akola Safed & 0.44 & 5.39 & 4.24 & 0.17 & 4.93 & 2.80 \\
\hline Agrifound Light Red & 0.48 & 1.72 & 1.48 & 0.11 & 25.92 & 7.16 \\
\hline Bhima Subhra & 0.66 & 4.21 & 3.90 & 0.31 & 17.28 & 0.59 \\
\hline Arka Bheem & 0.45 & 2.80 & 1.85 & 0.06 & 16.04 & 3.53 \\
\hline Kalyanpur Red Round & 0.55 & 3.03 & 2.21 & 0.55 & 13.57 & 0.28 \\
\hline Bhima Raj & 0.58 & 2.54 & 2.18 & 0.05 & 14.81 & 0.49 \\
\hline Bhima Shakti & 0.61 & 2.49 & 2.40 & 0.25 & 11.11 & 0.3 \\
\hline Hisar 2 & 0.60 & 1.27 & 1.12 & 0.07 & 24.68 & 0.54 \\
\hline Arka Kirtiman & 0.54 & 7.15 & 6.83 & 0.10 & 1.23 & 2.73 \\
\hline Arka Niketan & 0.69 & 6.18 & 5.28 & 0.08 & 2.46 & 3.31 \\
\hline Bhima Red & 0.47 & 1.08 & 1.03 & 0.03 & 22.22 & 0.38 \\
\hline Bhima Kiran & 0.67 & 1.65 & 1.08 & 0.68 & 23.32 & 0.39 \\
\hline Sukhsagar & 0.66 & 1.94 & 1.78 & 0.65 & 24.55 & 0.31 \\
\hline
\end{tabular}




\begin{tabular}{|c|c|c|c|c|c|c|}
\hline $\mathrm{CD}(0.05)$ & 0.03 & 0.23 & 0.42 & 0.40 & 3.88 & 2.34 \\
\hline $\mathrm{SE}(\mathrm{m}) \pm$ & 0.01 & 0.08 & 0.15 & 0.14 & 1.35 & 0.81 \\
\hline $\mathrm{CV}$ & 3.95 & 4.66 & 10.02 & 131.35 & 1.92 & 80.70 \\
\hline
\end{tabular}

\section{Conclusion}

From the present investigation, we conclude that genotype Sukhsagar was best concerning plant height at 30 DAT and 90 DAT; the number of leaves at 30 DAT, 60 DAT and 90 DAT; equatorial diameter, total soluble solids, dry matter (\%), total sugar $(\%)$, vitamin $\mathrm{C}(\mathrm{mg} / \mathrm{g})$, pyruvic acid $(\mu \mathrm{mole} / \mathrm{g})$. The genotype Arka Kirtiman was found superior in terms of total yield and marketable yield. Punjab Naroya had the highest phenol content. The genotypes Bhima Raj, HO-3, Arka Bheem, Arka Niketan exhibited superiority in terms of number of bulbs per plot, number of days to maturity, polar diameter, number of scales per bulb respectively. Hence, for carrying out future breeding programme and to exploit hybrid vigour in onion, emphasis should be given to these best performing genotypes.

\section{Acknowledgement}

The authors are thankful to Department of Vegetable Science, Faculty of Horticulture, Bidhan Chandra Krishi Viswavidyalaya, for providing all the necessary facilities during research work.

\section{References}

1. Baghizadeh A, Baniasadi F, Bonjar GHS, Sirchi GRS, Massumi H, Jorjandi $\mathrm{M}$ et al. Biocontrol of Botrytis allii Munn. the causal agent of neck rot, the post-harvest disease in onion, by use of a new Iranian isolate of Streptomyces. American Journal of Agriculture and Biological Sciences. 2009; 4:72-78.

2. Bal S, Maity TK, Sharangi AB, Maji A. Screening of onion (Allium cepa L.) germplasm against purple blotch disease. Journal of Pharmacognosy and Phytochemistry. 2019; 8(6):546-548.

3. Bal S, Maity TK, Sharangi AB, Majumdar A. Quality assessment in association with yield attributes contributing improved yield in onion (Allium cepa L.). Journal of Crop and Weed. 2019; 15(3):107115.doi: 10.22271/09746315.2019.v15.i3.1245

4. Bal S, Maity TK, Maji A. Genetic Divergence Studies for Yield and Quality Traits in Onion (Allium cepa L.). International Journal of Current Microbiology and Applied Sciences. 2020; 9(06):3201-3208. doi: https://doi.org/10.20546/ijcmas.2020.906.383.

5. Bhangale GT, Joi MB. Screening of onion cultivar for resistance to purple blotch and thrips. Journal of Maharashtra Agricultural University. 1985; 10:355-356.

6. Das R, Gowda V, Pandey H. Evaluation of Different Onion (Allium cepa L.) Genotypes for Yield and Quality Parameters in Kharif Season under Bengaluru Condition. International Journal of Current Microbiology and Applied Sciences. 2017; 6(11):2393-2398.

7. Fritisch, Friesen, Evolution, Domestication and Taxonomy. Allium Crop Science, 2002.

8. Jain N. Study on genetic variability and character association in onion (Allium cepa L.) genotypes. M.Sc. (Ag) Thesis. JNKVV. Jabalpur, 2012.

9. Javadzadeh A, Ghorbanihaghjo A, Bonyadi S, Rashidi M $\mathrm{R}$, Mesgari M, Rashtchizadeh N et al. Preventive effect of onion juice on selenite-induced experimental cataract. Indian Journal of Ophthalmology. 2009; 57:185-189.
10. Ram B, Kumar U. Performance of onion (Allium cepa L.) genotypes for growth, yield and quality. International Journal of Chemical Studies. 2018; SP4:128-131. 